\title{
Pengaruh Citra Merek dan Kualitas Produk Terhadap Minat Beli Snack Coklat Tobelo Pada PT. Bumi Tangerang Coklat Utama
}

\author{
Bernadus Alvin Aprian', Adrian Hidayat ${ }^{2}$ \\ Universitas Buddhi Dharma \\ ahnangka67@yahoo.com
}

\begin{abstract}
Abstrak
Banyak faktor yang mempengaruhi perilaku pembelian seseorang terhadap suatu produk. Tiap individu mempunyai keinginan dan selera yang berbeda-beda. Citra Merek dan Kualitas Produk merupakan faktor yang sangat berpengaruh terhadap Minat Beli Konsumen. Selain kedua faktor tersebut, masih terdapat faktor lainnya yang dapat mempengaruhi minat pembelian. Penelitian ini bertujuan untuk mengetahui besar pengaruh dari citra merek dan kualitas produk terhadap minat beli. Penelitian ini dilakukan dengan menggunakan metode survey. Ruang lingkup dalam penelitian ini adalah lingkungan Universitas Buddhi Dharma. Pengambilan sampel dengan jumlah 100 orang responden dilakukan dengan teknik sampling insidental. Analisis data dilakukan dengan uji hipotesis, uji validitas, uji reabilitas, analisis regresi sederhana dan berganda, analisis korelasi sederhana dan berganda, dan analisis koefesien determinasi $\left(\mathrm{R}^{2}\right)$ dalam mengetahui seberapa besar pengaruh dan signifikansi Citra Merek dan Kualitas Produk Terhadap Minat Beli Konsumen Tobelo di PT. Bumi Tangerang Coklat Utama, serta mengetahui variabel yang mempunyai pengaruh paling dominan. Berdasarkan analisis data yang dilakukan dalam penelitian ini, dapat disimpulkan bahwa variable (X1) yaitu citra merek, berpengaruh positif dan signifikan terhadap variable (Y) yaitu minat beli konsumen dengan nilai koefiesien sebesar 0,860 (cukup kuat). Variabel (X2) yaitu kualitas produk berpengaruh positif dan signifikan terhadap variable (Y) minat beli dengan nilai koefisien sebesar 0,760 (cukup kuat). Variabel (X1) citra merek dan variable (X2) kualitas produk berpengaruh positif dan signifikan dengan nilai signifikan keduanya yang cukup kuat. Dari hasil uji F, model 1 didapat nilai 277.111 dan model 2 didapat nilai 162.894, dimana nilai tersebut lebih besar dari F tabel sebesar 3,09, maka Ho ditolak dan Ha diterima, artinya terdapat hubunga positif antara variabel Citra Merek terhadap Minat beli konsumen. Dari hasil uji t didapat thitung Citra merek sebesar 9,028 dan thitung Kualitas produk sebesar 3.668, dimana nilai tersebut lebih besar dari 1,98447, maka Ho ditolak dan Ha diterima, artinya terdapat hubungan yang signifikan antara citra merek dan kualitas produk terhadap minat beli konsumen.
\end{abstract}

Kata kunci: Citra, Kualitas, Produk, Minat Beli, Konsumen

\section{Pendahuluan}

Kakao merupakan salah satu komoditas ekspor yang dapat memberikan kontribusi untuk peningkatan devisa negara. Indonesia merupakan salah satu negara pemasok utama kakao dunia setelah Pantai Gading (38,3\%) dan Ghana (20,2\%). Komoditas kakao mempunyai peranan penting sebagai sumber pendapatan dan penyerapan tenaga kerja. Produksi kakao nasional meningkat pesat dengan rata-rata 7,78\% per tahun. Ekspor kakao olahan (mentega, bubuk, pasta,

${ }^{1}$ Korespondensi: Bernandus Alvin Aprian. Universitas Buddhi Dharma, Jl. Imam Bonjol No 41 Karawaci Ilir, Tangerang.

${ }^{2}$ Korespondensi: Adrian Hidayat. Universitas Buddhi Dharma, Jl. Imam Bonjol No 41 Karawaci Ilir, Tangerang. ahnangka67@yahoo.com 
dan cokelat) terus meningkat secara signifikan. Peningkatan volume ekspor produk kakao olahan tersebut menunjukkan perkembangan yang pesat dalam industri pengolahan kakao di dunia.

Konsumsi cokelat semakin meningkat sejalan dengan arus globalisasi informasi dan daya beli masyarakat, diperlukan diversifikasi atau penganekaragaman produk cokelat untuk memperluas jangkauan dan daya beli masyarakat dan dapat meningkatkan kesehatan dengan memanfaatkan sumber daya alam dan sumber daya manusia dengan semaksimal mungkin dan meminimalkan biaya produksi sehingga dapat terjangkau oleh seluruh lapisan masyarakat. Menurut data Badan Pusat Statistik (2007) hasil produksi cokelat di Indonesia yaitu pada bubuk cokelat tidak manis mencapai $11.039 .647 \mathrm{~kg}$, produk cokelat batangan mencapai $3.106 .336 \mathrm{~kg}$, produk cokelat butiran $5.648 .891 \mathrm{~kg}$, produk bubuk cokelat manis mencapai $26.011 .959 \mathrm{~kg}$, produk cokelat cair $415.320 \mathrm{~kg}$, produk permen cokelat $2.453 .306 \mathrm{~kg}$, dan produk olahan cokelat lainnya sebanyak $29.396 .527 \mathrm{~kg}$. Cokelat di dalam industri pembuatannya, terbagi menjadi tiga tipe yakni: Dark chocolate, milk chocolate, dan white chocolate. Dark chocolate terdiri dari sejumlah campuran cokelat padat atau cairnya, tambahan cocoa butter, gula, dan vanilla yang dicampur dengan menggunakan proses conched dan tempered ( didinginkan pada kondisi tertentu ) untuk menjaga agar gula dan lemak terkristalisasi dalam bentuk yang paling stabil. Pembuatan milk chocolate, ditambahkan lagi susu atau cream, susu cair, atau susu bubuk ke dalam campuran dark chocolate tadi.

White chocolate tidak mengandung chocolate liquor (pasta cokelat) hanya terdiri dari cocoa butter, susu, lemak susu, dan pemanis seperti gula atau sirup yang kaya akan fruktosa. Cokelat merupakan hasil pengolahan biji kakao yang paling banyak digemari. Dalam hal ini cokelat merupakan kategori makanan yang mudah dicerna oleh tubuh dan mengandung banyak vitamin seperti vitamin A1, B1, B2, C, D, dan E serta beberapa mineral seperti fosfor, magnesium, zat besi, zinc, dan juga tembaga. Selain itu cokelat terkenal mengandung antioksida dan flavonoid yang sangat berguna untuk mencegah masuknya radikal bebas ke dalam tubuh yang bisa menyebabkan kanker. Beberapa kandungan senyawa aktif cokelat seperti kafein, theobromine, methyl-xanthine, dan phenylethylalanine dipercaya dapat mengurangi kelelahan sehingga bisa digunakan sebagai obat anti depresi. Salah satu perusahaan yang memproduksi berbagai macam coklat sebagai produk utamanya yaitu PT Bumi Tangerang Coklat Utama (BTCU).

PT Bumi Tangerang Coklat Utama sudah memproduksi coklat sejak awal didirikan nya perusahaan tersebut, dari awal berdiri hingga kini produk coklat BTCU mengalami banyak perubahan mulai dari bentuk, rasa, hingga kemasan. Citra merek merupakan aset perusahaan PT. Bumi Tangerang Cokelat Utama agar pembeli tetap pada pilihanya, dan bahkan citra merek mampu mempengaruhi pembeli menentukan pilihannya Kualitas produk Tobelo mampu memberikan kepuasan rasa bagi pembelinya. Dengan kualitas yang dimilikinya, coklat Tobelo mampu memenangi persaingan pasar

\section{Landasan Pustaka}

\section{Pemasaran}

Menurut Thamrin Abdullah dan Francis Tantri $(2013,2)$ dalam bukunya berjudul Manajemen Pemasaran menyatakan bahwa : "Pemasaran (marketing) adalah suatu sistem total dari keinginan bisnis yang dirancang untuk merencanakan, menentukan harga, mempromosikan dan mendistribusikan barang-barang yang dapat memuaskan keinginan dan jasa baik kepada para konsumen saat ini maupun konsumen potensial".

Menurut Danang Sunyoto $(2012,18)$ dalam bukunya Dasar-dasar Manajemen Pemasaran menyatakan bahwa : "Pemasaran ujung tombak perusahaan. Dalam dunia persaingan merupakan yang semakin ketat, perusahaan dituntut agar tetap bertahan dan berkembang" 
Menurut Danang Sunyoto $(2012,19)$ dalam bukunya Manajemen Pemasaran menyatakan bahwa : "Pemasaran adalah kegiatan manusia yang bertujuan untuk memuaskan kebutuhan dan keinginan langganan melalui proses pertukaraan dan pihak-pihak yang berkepentingan dengan perusahaan".

Dari pengertian para ahli diatas, dapat disimpulkan bahwa pemasaran merupakan suatu proses yang dilakukan oleh perusahaan untuk dapat memenuhi kebutuhan dan keinginan konsumennya, yang secara tidak langsung perusahaan mempertahankan hubungannya dengan konsumennya demi kelangsungan hidup usahanya.

\section{Citra Merek}

Menurut Kotler dalam buku Danang Suyonto $(2012,102)$ yang berjudul Dasar-dasar Manajemen Pemasaran menyatakan bahwa : "Merek adalah sebuah nama, istilah, tanda, simbol, atau rancangan atau bahkan kombinasi dari semuanya tadi, yang dimaksudkan untuk menyebutkan barang-barang atau jasa dari seorang sekelompok penjual agra terbedakan dari para pesaingnya".

Menurut Bruce J. Walker dalam buku Danang Suyonto $(2012,102)$ dalam bukunya yang berjudul Dasar-dasar Manajemen Pemasaran menyatakan bahwa : "Sebuah merek adalah suatu nama, istilah tanda, desain, atau gabungan semua yang diharapkan mengidentifikasi barang atau jasa dari seseorang atau sekelompok penjual".

Menurut Etta M Sangadji dan Sopiah $(2013,322)$ dalam bukunya yang berjudul Perilaku Konsumen menyatakan bahwa : "Merek adalah nama atau simbol yang bersifat membedakan (seperti logo, cap, atau kemasan) dengan maksud mengidentifikasi barang atau jasa dari seorang penjual atau penjual tertentu yang mampu membedakannya dari barang-barang yang dihasilkan oleh para pesaing". Berdasarkan definisi di atas dapat disimpulkan bahwa merek adalah suatu nama ataupun simbol yang melekat pada suatu produk, yang kemudian membedakannya dari produk lain sehingga gampang untuk dikenali.

\section{Kualitas Produk}

Produk adalah segala sesuatu yang dapat ditawarkan kepasar untuk mendapatkan perhatian, dibeli, digunakan, atau dikonsumsi yang dapat memuaskan keinginan atau kebutuhan konsumen.

Menurut Sudaryono $(2014,354)$ dalam bukunya yang berjudul Perilaku Konsumen Dalam Prespektif Pemasaran menyatakan bahwa: „Produk adalah hasil akhir yang mengandung elemen- elemen fisik, jasa dan hal-hal yang simbolis yang dibuat dan dijual oleh perusahaan untuk memberikan kepuasan dan keuntungan bagi pembelinya". Menurut Buchari Alma $(2016,139)$ dalam bukunya Manajemen Pemasaran dan Pemasaran Jasa menyatakan bahwa : Produk adalah segala sesuatu yang dapat ditawarkan di pasar, untuk memuaskan kebutuhan dan keinginan konsumen. Produk terdiri atas barang, jasa, pengalaman, events, orang, tempat, kepemilikan, organisasi, informasi dan ide.

Menurut Zulian Yamit $(2013,68)$ dalam bukunya Manajemen Kualitas Produk dan Jasa, menyatakan bahwa: Kualitas merupakan suatu kondisi dinamis yang berhubungan dengan produk, jasa, manusia, proses dan lingkungan yang memenuhi atau melebihi harapan”.

Menurut Abdul Manap (2016,225) dalam bukunya Revolusi Manajemen Pemasaran, menyatakan bahwa: "Produk ialah seperangkat atribut baik berwujud maupun tidak berwujud, termasuk didalamnya masalah warna, harga, nama baik pabrik, nama baik toko yang menjual (pengecer), 
dan pelayanan pabrik serta pelayanan pengecer, yang diterima oleh pembeli guna memuaskan keinginannya."

\section{Minat Beli}

Minat adalah tahap kecenderungan responden untuk bertindak sebelum keputusan membeli benar-benar dilaksanakan. Terdapat perbedaan antara pembeli aktual dan minat pembelian. Bila pembelian aktual adalah pembelian yang benar-benar dilakukan oleh konsumen, maka minat pembelian adalah niat untuk melakukan pembelian pada kesempatan mendatang. Meskipun merupakan pembelian yang belum tentu akan dilakukan pada masa mendatang namun pengukuran terhadap minat pembelian umumnyadilakukan guna memaksimalkan prediksi terhadap pembelian aktual itu sendiri. Minat belimerupakan keinginan yang muncul dalam diri konsumen terhadap suatu produk sebagai dampak dari suatu proses pengamatan dan pembelajaran konsumen atau individu tersebut terhadap suatu produk.

Menurut Ali Hasan (201 4,173) dalam bukunya yang berjudul Marketing dan Kasus -Kasus Pilihan menyatakan bahwa : "Minat beli merupakan pernyataan mental dari konsumen yang merefleksikan rencana pembelian sejumlah produk dengan merek tertentu".

\section{Metode Penelitian \\ Sampel}

Sampel yang digunakan sebanyak 30. karena terdapat dua variabel independen dan satu variabel dependen, jadi $3 \times 10=30$.

\section{Operasionalisasi Variabel}

Variable yang digunakan ini harus menjadi definisi operasional variable dengan tujuan untuk memberikan batasan dan penjelasan dalam rangka membatasi analisa. Maka dari itu di sini dituliskan batasan variable penelitian kedalam bentuk table seperti ini :

\section{Tabel 1. Operasional Variabel}

\begin{tabular}{llllr}
\hline \multicolumn{1}{c}{ Variabel } & \multicolumn{1}{c}{ Sub Variabel } & \multicolumn{1}{c}{ Indikator } & Skala \\
\hline Citra & Merek & 1. Asosiasi merek & 1. Pengenalan merek & ORDINAL \\
(X1) & 2. Dukungan asosiasi merek & 2. Kesadaran merek & \\
& 3. Kekuatan asosiasi merek & 3. Kesan kualitas merek & \\
& 4. Keunikan asosiasi merek & 4. Loyalitas merek & \\
& & & 5. Asosiasi merek & \\
& & 6. Identitas merek & \\
& & 7. Personalitas merek & \\
& & & 8. Sikap dan perilaku merek & \\
& & & 9. Manfaat merek & \\
& & & 10. Keunggulan merek & \\
\hline
\end{tabular}

\begin{tabular}{llll}
\multicolumn{4}{l}{ Sumber : Freddy Rangkuti (2012,7) dalam bukunya "Dasar-Dasar Manajemen" } \\
\hline Kualitas & 1. Performance & 1. Kinerja & ORDINAL \\
Produk (X2) & 2. Feature & 2. Daya tahan \\
& 3. Percieved Quality & 3. Kesesuaian spesifikasi \\
& 4. Conformance & 4. Fitur \\
5. Aesthetics & 5. Reliabilitas \\
& & 6. Estetika \\
& 7. Kesan Kualitas \\
& 8. Karakteristik produk \\
& 9. Kualitas bahan baku
\end{tabular}




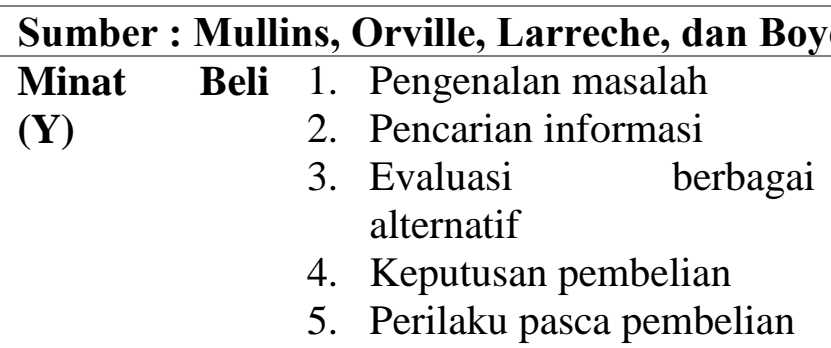

10. Kualitas produk

\section{(2012) "Leader of Management"}

1. Kebutuhan konsumen

ORDINAL

2. Pertimbangan membeli

3. Kepuasan konsumen

4. Kecocokan produk

5. Keterkaitan konsumen

6. Penyesuaian harga

7. Informasi jelas

8. Gaya hidup

9. Pelayanan

10. Ketersediaan produk

\section{Sumber : Basu Swasta (2012,239) dalam bukunya "Manajemen Pemasaran Modern"}

\section{Teknik Analisa Data}

Digunakan untuk menyederhanakan data agar data lebih mudah diinterprestasikan atau dijelaskan. Analisis dalam penelitian ini dilakukan dengan menggunakan teknik analisis regresi berganda untuk mengolah dan membahas data yang telah diperoleh dan untuk menguji hipotesis yang diajukan. Teknik analisis regresi berganda dipilih untuk digunakan pada penelitian ini karena penelitian ini menggunakan data primer dengan 2 variabel $\mathrm{X}$ dan 1 variabel $\mathrm{Y}$. Teknik regresi berganda dapat menyimpulkan secara langusng mengenai pengaruh masing-masing variable bebas yang digunakan secara parsial maupun secara bersama-sama.

Fleksibilitas dan adaptifitas dari metode ini mempermudah peneliti untuk melihat suatu keterkaitan dari beberapa variable sekaligus. Regresi berganda juga memperkirakan kemampuan prediksi dari serangkaian variable bebas (independen) terhadap variable terikat (dependen).

Model persamaan regresinya adalah sebagai berikut :

$\mathrm{Y}=\beta 0+\beta 1 \mathrm{X} 1+\beta 2 \mathrm{X} 2$

Dimana :

Y : Keputusan pembelian konsumen

$\beta 0$ : Konstanta / Intercept

$\beta 1$ : Koefisien regresi pengaruh harga

$\beta 2$ : Koefisien regresi pengaruh kualitas produk

$\mathrm{X} 1$ : Variabel pengaruh harga

$\mathrm{X} 2$ : Variabel pengaruh kualitas produk

\section{Hasil}

\section{Berdasarkan Responden}

Tabel 2. Data Berdasarkan Jenis Kelamin

\begin{tabular}{|cl|c|c|c|c|}
\hline & Frequency & Percent & $\begin{array}{l}\text { Valid } \\
\text { Percent }\end{array}$ & $\begin{array}{l}\text { Cumulative } \\
\text { Percent }\end{array}$ \\
\hline Valid Laki-laki & 47 & 47.0 & 47.0 & 47.0 \\
& Perempuan & 53 & 53.0 & 53.0 & 100.00 \\
& Total & 100 & 100.0 & 100.0 & \\
\hline
\end{tabular}

Berdasarkan data diatas dapat dilihat bahwa terdapat jenis kelamin laki-laki dan perempuan. Dimana banyaknya responden yang berjenis kelamin laki-laki sebanyak 47 orang dengan persentase $47 \%$ sedangkan responden yang berjenis kelamin perempuan sebanyak 53 orang dengan persentase 53\%. Dimana jumlah responden terbanyak adalah responden berjenis kelamin perempuan sebanyak 53 orang dengan tingkat persentase $53 \%$. 
Usia

Tabel 3. Data Responden Berdasarkan Usia

\begin{tabular}{|l|c|c|c|c|}
\hline & Frequency & Percent & $\begin{array}{l}\text { Valid } \\
\text { Percent }\end{array}$ & $\begin{array}{l}\text { Cumulative } \\
\text { Percent }\end{array}$ \\
\hline Valid $<20$ tahun & 31 & 31.0 & 31.0 & 31.0 \\
20-23 tahun & 47 & 47.0 & 47.0 & 78.0 \\
23>tahun & 22 & 22.0 & 22.0 & 100.0 \\
Total & 100 & 100.0 & 100.0 & \\
\hline
\end{tabular}

Berdasarkan data diatas dilihat bahwa terdapat tingkatan usia. Dimana tingkat usia kurang dari 20 tahun sebanyak 31 orang dengan presentase 31\%, tingkat usia 21-23 tahun sebanyak 47 orang dengan presentase $47 \%$ dan tingkat usia lebih dari 23 tahun sebanyak 22 orang dengan presentase $22 \%$. Dimana tingkat usia terbanyak adalah dengan tingkat usia 20-23 tahun sebanyak 47 orang dengan presentase $47 \%$.

Pendidikan

Tabel 4. Data Responden Berdasarkan Pendidikan

\begin{tabular}{|cl|c|c|c|c|}
\hline & Frequency & Percent & $\begin{array}{l}\text { Valid } \\
\text { Percent }\end{array}$ & $\begin{array}{l}\text { Cumulative } \\
\text { Percent }\end{array}$ \\
\hline Valid & SMA & 34 & 34.0 & 34.0 & 34.0 \\
& D3 & 6 & 6.0 & 6.0 & 40.0 \\
& S1 & 60 & 60.0 & 60.0 & 100.0 \\
& Total & 100 & 100.0 & 100.0 & \\
\hline
\end{tabular}

Berdasarkan data diatas dilihat bahwa terdapat tingkatan pendidikan. Dimana tingkat SMA sebanyak 34 orang dengan presentase 34\%, tingkat D3 sebanyak 6 orang dengan presentase $6 \%$, tingkat S1 sebanyak 60 orang dengan presentase 60\%. Dimana tingkat pendidikan terbanyak adalah dengan tingkat S1 sebanyak 60 orang dengan presentase $60 \%$.

\section{Uji Validitas dan Reliabilitas Citra Merek (X1)}

Dalam penelitian ini penulis membuat 10 pernyataan yang dinyatakan untuk variabel X1 mengenai Citra Merek. Untuk mengetahui lebih lanjut, apakah semua pernyataan tersebut valid dan reliabel, maka dapat dilakukan uji validitas dan reliabilitas.

\section{Tabel 5. Case Processing Summary}

\begin{tabular}{|cl|c|c|}
\hline & & $\mathbf{N}$ & \% \\
\hline Cases & Valid $^{*}$ & 100 & 100.0 \\
& Excluded $^{\mathrm{a}}$ & 0 & .0 \\
& Total & 100 & 100.0 \\
\hline
\end{tabular}

a. Listwise deletion based on all variables in the procedure.

Pada tabel 5 Case Processing Summary dapat dilihat bahwa responden yang diteliti pada hasil kuesioner mengenai variabel citra merek berjumlah 100 orang dan semua data tidak ada yang dikeluarkan (exclude) dari analisis.

Tabel 6. Reliability Statistics

\begin{tabular}{|c|c|}
\hline $\begin{array}{l}\text { Cronbach's } \\
\text { Alpha }\end{array}$ & N of Items \\
\hline .804 & 10 \\
\hline
\end{tabular}


Pada tabel 6 reliability statistics diatas dapat dilihat bahwa nilai Cronbrach's Alpha adalah sebesar 0,804 dengan jumlah 10 pernyataan. Jika dibadingkan dengan nilai alpha Romie Priyastama $(2017,170)$ dalam bukunya "Buku Sakti Kuasai SPSS Pengolahan Data \& Analisis Data", maka nilai Cronbrach's Alpha dan variabel citra merek lebih besar dari pada nilai a = 0,60. Jadi dapat disimpulkan bahwa semua kuesioner tentang citra merek tersebut terbukti dapat diterima dan reliabel.

Tabel 7. Item-Total Statistics

\begin{tabular}{|l|c|c|c|c|}
\hline & $\begin{array}{l}\text { Scale Mean if } \\
\text { Item Deleted }\end{array}$ & $\begin{array}{l}\text { Scale Variance } \\
\text { if Item Deleted }\end{array}$ & $\begin{array}{l}\text { Corrected Item- } \\
\text { Total } \\
\text { Correlation }\end{array}$ & $\begin{array}{l}\text { Cronbach's } \\
\text { Alpha if Item } \\
\text { Deleted }\end{array}$ \\
\hline P1X1 & 38.8900 & 8.240 & .698 & .761 \\
P2X1 & 38.8800 & 9.056 & .374 & .799 \\
P3X1 & 38.8600 & 8.465 & .630 & .769 \\
P4X1 & 38.8900 & 9.109 & .379 & .798 \\
P5X1 & 38.9400 & 9.431 & .296 & .807 \\
P6X1 & 38.8500 & 8.876 & .481 & .786 \\
P7X1 & 38.9100 & 8.164 & .708 & .759 \\
P8X1 & 38.7800 & 9.103 & .370 & .799 \\
P9X1 & 38.9100 & 8.951 & .483 & .786 \\
P10X1 & 38.8000 & 9.172 & .410 & .794 \\
\hline
\end{tabular}

1. Tabel Item-Total Statistic menunjukan hasil perhitungan validitas untuk 10 pernyataan.

2. Menentukan besarnya nilai rtabel dengan ketentuan tingkat kepercayaan (degree of freedom $=$ df) jumlah responden dikurangi 2 atau 100-2 = 98 dengan tingkat signifikan 5\% maka rtabel sebesar 0,1966. 10

3. Membandingkan rtabel dengan setiap butir rhitung pernyataan dengan cara membandingkan output correlated item total correlation dengan 0,1966 rtabel.

4. Jika dibandingkan dengan rtabel pada kolom correlated item total correlation. Nilai rhitung semua pernyataan tentang citra merek lebih besar rtable artinya semua pernyataan sudah valid.

\section{Uji Validitas dan Reliabilitas Kualitas Produk (X2)}

Dalam penelitian ini penulis membuat 10 pernyataan yang dinyatakan untuk variabel X2 mengenai Kualitas Produk. Untuk mengetahui lebih lanjut, apakah semua pernyataan tersebut valid dan reliabel, maka dapat dilakukan uji validitas dan reliabilitas.

Tabel 8. Case Processing Summary

\begin{tabular}{|cl|l|l|}
\hline & & $\mathbf{N}$ & \% \\
\hline Cases & Valid & 100 & 100.0 \\
& Excluded $^{\mathrm{a}}$ & 0 & .0 \\
& Total & 100 & 100.0 \\
\hline
\end{tabular}

a. Listwise deletion based on all variables in the procedure.

Dari tabel case processing summary diatas dapat dilihat bahwa responden yang diteliti pada hasil kuesioner mengenai variabel kualitas produk berjumlah 100 orang dan semua data tidak ada yang dikeluarkan (exclude) dari analisis.

Tabel 9. Reliability Statistics

\begin{tabular}{|l|l|}
\hline $\begin{array}{l}\text { Cronbach's } \\
\text { Alpha }\end{array}$ & N of Items \\
\hline
\end{tabular}




\section{.801}

10

Pada tabel 9 Reliability Statistics diatas dapat dilihat bahwa nilai Cronbrach's Alpha adalah sebesar 0,801 dengan jumlah 10 pernyataan. Jika dibadingkan dengan nilai alpha Romie Priyastama $(2017,170)$ dalam bukunya "Buku Sakti Kuasai SPSS Pengolahan Data \& Analisis Data", maka nilai Cronbrach's Alpha dan variabel kualitas produk lebih besar dari pada nilai a $=$ 0,60. Jadi dapat disimpulkan bahwa semua kuesioner tentang kualitas produk tersebut terbukti dapat diterima dan reliabel.

Tabel 10. Item-Total Statistics

\begin{tabular}{|l|c|c|c|c|}
\hline & $\begin{array}{l}\text { Scale Mean if } \\
\text { Item Deleted }\end{array}$ & $\begin{array}{l}\text { Scale Variance } \\
\text { if Item Deleted }\end{array}$ & $\begin{array}{l}\text { Corrected Item- } \\
\text { Total } \\
\text { Correlation }\end{array}$ & $\begin{array}{l}\text { Cronbach's } \\
\text { Alpha if Item } \\
\text { Deleted }\end{array}$ \\
\hline P1Y & 38.0900 & 10.143 & .368 & .795 \\
P2Y & 38.1500 & 10.189 & .335 & .799 \\
P3Y & 37.9700 & 9.848 & .487 & .782 \\
P4Y & 37.9200 & 10.135 & .423 & .789 \\
P5Y & 37.9300 & 9.823 & .505 & .780 \\
P6Y & 38.1100 & 9.574 & .456 & .786 \\
P7Y & 38.2500 & 9.644 & .494 & .781 \\
P8Y & 38.0500 & 9.301 & .604 & .768 \\
P9Y & 38.0800 & 9.711 & .473 & .784 \\
P1Y & 38.2400 & 9.093 & .609 & .766 \\
\hline
\end{tabular}

1. Tabel Item-Total Statistic menunjukan hasil perhitungan validitas untuk 10 pernyataan.

2. Menentukan besarnya nilai rtabel dengan ketentuan tingkat kepercayaan (degree of freedom $=$ df) jumlah responden dikurangi 2 atau $100-2=98$ dengan tingkat signifikan 5\% maka rtabel sebesar 0,1966 .

3. Membandingkan rtabel dengan setiap butir rhitung pernyataan dengan cara membandingkan output correlated item total correlation dengan 0,1966 rtabel.

4. Jika dibandingkan dengan rtabel pada kolom correlated item total correlation. Nilai rhitung semua pernyataan tentang kualitas produk lebih besar rtable artinya semua pernyataan sudah valid.

\section{Uji Reabilitas dan Vadilitas Variabel Minat Beli Konsumen (Y)}

Dalam penelitian ini penulis membuat 10 pernyataan yang dinyatakan untuk variabel Y tentang Minat Beli Konsumen. Untuk mengetahui lebih lanjut, apakah semua pernyatan tersebut reliable, maka dapat dilakukan uji reabilitas dengan hasil uji reabilitas sebagai berikut :

Tabel 11. Case Processing Summary

\begin{tabular}{|cl|l|l|}
\hline & & $\mathbf{N}$ & \% \\
\hline Cases & Valid $^{*}$ & 100 & 100.0 \\
& Excluded $^{\mathrm{a}}$ & 0 & .0 \\
& Total & 100 & 100.0 \\
\hline
\end{tabular}

a. Listwise deletion based on all variables in the procedure.

Pada tabel 8 Case Processing Summary dapat dilihat bahwa responden yang diteliti pada hasil kuesioner mengenai variabel minat beli 10 konsumen berjumlah 100 orang dan semua tidak ada yang dikeluarkan (exclude) dari analisis.

Tabel 12. Reliability Statistics

\begin{tabular}{|l|l|}
\hline $\begin{array}{l}\text { Cronbach's } \\
\text { Alpha }\end{array}$ & N of Items \\
\hline
\end{tabular}




\section{.814}

Pada tabel 9 Reliability Statistics diatas dapat dilihat bahwa nilai Cronbrach's Alpha adalah sebesar 0,814 dengan jumlah 10 pernyataan. Jika dibandingkan dengan nilai alpha Romie Priyastama $(2017,170)$ dalam bukunya "Buku Sakti Kuasai SPSS Pengolahan Data \& Analisis Data", maka nilai Cronbrach's Alpha dan variabel minat beli lebih besar dari pada nilai a = 0,60. Jadi dapat disimpulkan bahwa semua kuesioner tentang minat beli tersebut terbukti dapat diterima dan reliabel.

Tabel 13. Item-Total Statistics

\begin{tabular}{|l|c|c|c|c|}
\hline & $\begin{array}{l}\text { Scale Mean if } \\
\text { Item Deleted }\end{array}$ & $\begin{array}{l}\text { Scale Variance } \\
\text { if Item Deleted }\end{array}$ & $\begin{array}{l}\text { Corrected Item- } \\
\text { Total } \\
\text { Correlation }\end{array}$ & $\begin{array}{l}\text { Cronbach's } \\
\text { Alpha if Item } \\
\text { Deleted }\end{array}$ \\
\hline P1Y & 38.6500 & 9.301 & .552 & .792 \\
P2Y & 38.8000 & 9.111 & .492 & .798 \\
P3Y & 38.7000 & 9.182 & .593 & .788 \\
P4Y & 38.6200 & 9.046 & .574 & .789 \\
P5Y & 38.6000 & 9.313 & .504 & .796 \\
P6Y & 38.7000 & 9.646 & .457 & .801 \\
P7Y & 38.5800 & 9.478 & .408 & .808 \\
P8Y & 38.7600 & 9.800 & .352 & .812 \\
P9Y & 38.7100 & 9.319 & .478 & .799 \\
P1Y & 38.7000 & 9.162 & .547 & .792 \\
\hline
\end{tabular}

1. Tabel Item-Total Statistic menunjukan hasil perhitungan validitas untuk 10 pernyataan.

2. Menentukan besarnya nilai rtabel dengan ketentuan tingkat kepercayaan (degree of freedom $=$ df) jumlah responden dikurangi 2 atau 100-2=98 dengan tingkat signifikan 5\% maka rtabel sebesar 0,1966 .

3. Membandingkan rtabel dengan setiap butir $\mathrm{r}_{\text {hitung }}$ pernyataan dengan cara membandingkan output correlated item total correlation dengan $0,1966 \mathrm{r}_{\text {tabel. }}$.

4. Jika dibandingkan dengan rtabel pada kolom correlated item total correlation. Nilai $\mathrm{r}_{\text {hitung }}$ semua pernyataan tentang minat beli lebih besar rtabel artinya semua pernyataan sudah valid.

Tabel 14. Hasil Perhitungan Anova

\begin{tabular}{|l|l|l|l|l|l|}
\hline Model & $\begin{array}{l}\text { Sum of } \\
\text { Squares }\end{array}$ & Df & Mean Square & F & Sig. \\
\hline 1. Regression & 825.886 & 1 & 825.886 & 277.111 & $.000 \mathrm{~b}$ \\
Residual & 292.074 & 98 & 2.980 & & \\
Total & 1117.960 & 99 & & & \\
\hline 2. Regression & 861.467 & 2 & 430.734 & 162.894 & $.000 \mathrm{c}$ \\
Residual & 256.493 & 97 & 2.644 & & \\
Total & 1117.960 & 99 & & & \\
\hline
\end{tabular}

a. Dependent Variable: minat_beli

b. Predictors: (Constant), citra_merek

c. Predictors: (Constant), citra_merek, kualitas_produk

1. Dari uji ANOVA didapat $F_{\text {Hitung }}$ untuk model 1 adalah 277.111 dengan tingkat signifikan 0,000 dimana angka $0,000<0,05$ dan juga $F_{\text {Hitung }}>F_{\text {tabel }}$ atau 277,111 $>3,09$, dengan demikian Ho ditolak dan Ha diterima artinya terdapat pengaruh antara variabel Citra Merek (X1) dan Kualitas Produk (X2) dengan Minat Beli Konsumen, maka model regresi tersebut sudah layak dan tepat. 
2. Dari uji ANOVA didapat $\mathrm{F}_{\text {Hitung }}$ untuk model 2 adalah 162.894 dengan tingkat signifikan 0,000 dimana angka $0,000<0,05$ dan juga $F_{\text {Hitung }}>F_{\text {tabel }}$ atau $162.894>3,09$, dengan demikian Ho ditolak dan Ha diterima artinya terdapat pengaruh antara variabel citra merek (X1) dan Kualitas Produk (X2) minat beli konsumen, maka model regresi tersebut sudah layak dan tepat.

Tabel 15. Hasil Perhitungan Koefisien Regresi Coefficients ${ }^{\mathrm{a}}$

\begin{tabular}{|l|l|l|l|l|l|}
\hline \multirow{2}{*}{ Model } & \multicolumn{2}{|l|}{$\begin{array}{l}\text { Unstandardized } \\
\text { Coefficients }\end{array}$} & $\begin{array}{l}\text { Standardized } \\
\text { Coefficients }\end{array}$ & \multirow{2}{*}{ Sig. } \\
\cline { 2 - 4 } & $\mathrm{B}$ & Std. Error & Beta & & \\
\hline (Constant) & 4.846 & 2.297 & & 2.109 & .037 \\
citra_merek & .883 & .053 & .860 & 16.647 & .000 \\
\hline (Constant) & 2.613 & 2.248 & & 1.162 & .248 \\
citra_merek & .678 & .075 & .660 & 9.028 & .000 \\
kualitas_produk & .262 & .072 & .268 & 3.668 & .000 \\
\hline
\end{tabular}

a. Dependent Variable: minat_beli

1. Untuk penyusunan persamaan regresi dari data diatas, dapat menggunakan nilai-nilai dari B yaitu Unstandardized Coefficients. Dari kolom B ini didapat nilai konstan sebesar 2.613, sedangkan untuk nilai koefisien variabel citra merek (X1) sebesar 0.678 dan variabel kualitas produk (X2) sebesar 0.262.

2. Dari nilai-nilai koefisien diatas persamaan regresi sebagai berikut :

$\mathrm{Y}=\mathrm{a}+\mathrm{b} 1 \mathrm{X} 1+\mathrm{b} 2 \mathrm{X} 2$

$\mathrm{Y}=$ Minat Beli Konsumen

$\mathrm{X}_{1}=$ Citra Merek.

$\mathrm{X}_{2}=$ Kualitas Produk.

$\alpha=$ Konstanta.

$\mathrm{b}_{1}=$ Koefisien regresi Citra Merek.

$\mathrm{b}_{2}=$ Koefisien regresi Kualitas Produk.

Maka diperoleh persamaan,

$\mathrm{Y}=2.613+0.678 \mathrm{X} 1+0.262 \mathrm{X} 2$

3. Pada saat variabel X1 (Citra Merek) terjadi peningkatan atau penurunan sebesar 1 poin maka variabel Y (Minat Beli Konsumen) akan mengalami peningkatan atau penurunan sebesar 0,678 .

4. Pada saat variabel $\mathrm{X} 2$ (Kualitas Produk) terjadi peningkatan atau penurunan sebesar 1 poin maka variabel $\mathrm{Y}$ (Minat beli Konsumen) akan mengalami peningkatan atau penurunan sebesar 0,262.

5. Untuk regresi berganda, angka korelasi pengaruh citra merek (X1) sebesar 0, 660 dan angka korelasi kualitas produk sebesar 0,268 adalah hasil yang didapat pada kolom Standardized Coefficient (Beta).

6. Pada kolom t digunakan pengujian t untuk menguji kebenaran dari hipotesis yang ada, dilakukan dengan cara membandingkan nilai tHitung yang diperoleh dengan nilai tabel Kriteria pengujian :

a. Jika $t_{\text {Hitung }}>\mathrm{t}_{\text {tabel }}$ maka Ho ditolak dan Ha diterima.

b. Jika $t_{\text {Hitung }}<\mathrm{t}_{\text {tabel }}$ maka Ho diterima dan Ha ditolak.

c. Pada kolom t diketahui bahwa tHitung untuk Citra Merek (X1) adalah sebesar 9.028 dengan menggunakan tabel distribusi normal $\mathrm{t}$ dan menggunakan tingkat keyakinan 
pengujian $(1-$ a) sebesar 95\% dan tingkat kesalahan (a) n-2 = $100-2=98$, maka diperoleh nilai distribusi tabel $\mathrm{t}$ adalah 1.984. Oleh karena $t_{\text {Hitung }}$ citra merek lebih besar dari $t_{\text {tabel }}$ atau $9.028>1.984$, maka Ho ditolak dan Ha diterima.

d. Kolom thitung untuk Kualitas Produk (X2) 3.668 dengan menggunakan tabel distribusi normal t dan menggunakan tingkat kesalahan (a) sebesar 95\% dan tingkat kesalahan (df) $\mathrm{n}-2=100-2=98$, maka diperoleh nilai distribusi tabel $\mathrm{t}$ adalah 1.984. Oleh karena itu

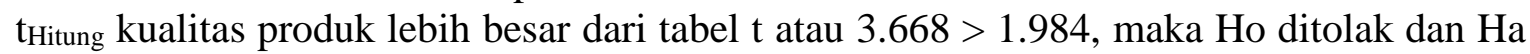
diterima.

7. Pada kolom signifikan digunakan untuk pengujian probabilitas. Kriteria pengujian :

Jika probabilitas $<0,05$ maka Ho ditolak dan Ha diterima.

Jika probabilitas > 0,05 maka Ho diterima dan Ha ditolak.

8. Terlihat pada kolom signifikan diketahui nilai probilitas untuk citra merek (Variabel X1) adalah 0,000 dan Kualitas Produk (Variabel X2) adalah 0.000 atau nilai probabilitas jauh di bawah 0,05, dengan demikian maka Ho ditolak dan Ha diterima, dengan kata lain koefisien regresi signifikan, artinya citra merek (variabel X1) dan kualitas produk (variabel X2) benarbenar sangat berpengaruh terhadap minat beli konsumen (variabel Y).

\section{Simpulan}

Dari hasil analisa data dan pembahasan mengenai pengaruh citra merek dan kualitas produk terhadap minat beli konsumen Tobelo pada PT. Bumi Tangerang Coklat Utama. Maka penulis dapat menarik kesimpulan sebagai berikut:

1. Variabel Citra Merek (X1) Berdasarkan hasil jawaban kuesioner mengenai citra merek Tobelo dengan jumlah sampel sebanyak 100 responden yang disebarkan oleh penulis dan telah diuji statistik frekuensi menjawab setuju pernyataan yang diajukan penulis mengenai citra merek.

2. Variabel Kualitas Produk (X2) Berdasarkan hasil jawaban kuesioner mengenai kualitas produk dengan jumlah sampel sebanyak 100 responden yang disebarkan oleh penulis dan telah diuji statistik frekuensi menjawab setuju pernyataan yang diajukan penulis mengenai kualitas produk.

3. Variabel Minat Beli Konsumen (Y) Berdasarkan hasil jawaban kuesioner mengenai minat beli konsumen Tobelo dengan jumlah sampel sebanyak 100 responden yang disebarkan oleh penulis dan telah diuji statistik frekuensi menjawab setuju pernyataan yang diajukan penulis mengenai minat beli konsumen.

4. Analisa variabel citra merek terhadap minat beli konsumen adalah besar pengaruh citra merek ditunjukan dengan nilai koefisien korelasi sebesar 0,860 mendekati 1, dimana korelasi memiliki hubungan yang positif dan kuat. Dari hasil pengujian $\mathrm{t}$ memperoleh $\mathrm{t}_{\text {Hitung }}>\mathrm{t}_{\text {tabel }}$ $(9.028>1.984)$ dan memiliki signifkasi sebesar 0,00 nilai ini lebih kecil dari $0,00(0,000>$ 0,05 ). Ini berarti Ho ditolak dan Ha diterima. Sehingga dapat disimpulkan bahwa citra merek berpengaruh positif dan signifikan terhadap minat beli konsumen.

5. Analisa variabel kualitas produk terhadap minat beli konsumen adalah besar pengaruh kualitas produk ditunjukan dengan nilai koefisien korelasi sebesar 0,746 mendekati 1, dimana korelasi memiliki hubungan yang positif dan kuat. Dari hasil pengujian $\mathrm{t}$ memperoleh tHitung $>$ ttabel (3.668 > 1.984 ) dan memiliki signifkasi sebesar 0.000 nilai ini lebih kecil dari 0,00 ( $0,000>0,05$ ). Ini berarti Ho ditolak dan Ha diterima. Sehingga dapat disimpulkan bahwa kualitas produk berpengaruh positif dan signifikan terhadap minat beli konsumen.

6. Analisa variabel citra merek dan kualitas produk terhadap minat beli konsumen adalah terdapat pengaruh yang kuat antara citra merek dan kualitas produk terhadap minat beli konsumen. Dari hasil pengujian $\mathrm{F}$ memperoleh nilai didapat $\mathrm{F}_{\text {Hitung }}>\mathrm{F}_{\text {tabel }}$ atau (277.111 > $3,09)$, nilai ini lebih kecil dari 0,05 $(0,000<0,05)$, dengan demikian Ho ditolak dan Ha 
diterima artinya terdapat pengaruh linear antara variabel citra merek dengan minat beli konsumen. Sedangkan dari hasil pengujian $\mathrm{F}$ memperoleh nilai didapat $\mathrm{F}_{\text {Hitung }}>\mathrm{F}_{\text {tabel }}$ $(162.894>3,09)$, nilai ini lebih kecil 0,05 $(0,000<0,05)$, dengan demikian Ho ditolak dan Ha diterima artinya terdapat pengaruh linear antara variabel kualitas produk dengan minat beli konsumen. Sehingga dapat disimpulkan bahwa citra merek dan kualitas produk berpengaruh positif dan signifikan terhadap minat beli konsumen.

\section{Daftar Pustaka}

Abdullah, Thamrin dan Francis Tantri. 2012. Manajemen Pemasaran. Depok: PT Raja Grafindo Persada.

Algifari. 2016. Statistika Induktif. Yogyakarta: Sekolah Tinggi Ilmu Manajemen YKPN.

Alma, Buchari. 2016. Manajemen Pemasaran dan Pemasaran Jasa. Bandung: Alfabeta.

Daryanto. 2011. Sari kuliah Manajemen Pemasaran: PT. Sarana Tutorial Nurani Sejahtera.

Ferdinand, Augusty. 2014. Metode Penelitian Manajemen. Semarang: Badan Penerbit Universitas Diponegoro.

Hasan, Ali. 2014. Marketing dan Kasus-Kasus Pilihan. Jakarta: CAPS (Center for Academic Publishing Service).

Lupiyoadi, Rambat 2013. Manajemen Pemasaran Jasa. Jakarta: Salemba Empat.

Manap Abdul. 2016. Revolusi Manajemen Pemasaran. Mitra Wacana Media.

Oentoro, Deliyanti. 2012. Manajemen Pemasaran Modern. Yogyakarta: LaksBang PRESS indo.

Priyastama, Romie.2017. Buku Sakti Kuasai SPSS. Start Up, Bantul: PT. Anak Hebat Indonesia.

Rangkuti, Freddy 2012. Dasar-Dasar Manajemen Merek. Jakarta: Gramedia Pustaka Utama.

Sangadji, Etta Mamang dan Sopiah. 2013. Perilaku Konsumen. Yogyakarta: Andi Pendekatan Praktisi Disertai Himpunan Jurnal Penelitian. Edisi Pertama.

Sarwono, Jonathan. 2017. Mengenal Prosedur-Prosedur Populer Dalam SPSS 23. Jakarta: PT. Alex Media Komputindo.

Sudaryono. 2017. Metodologi Penelitian. Jakarta: PT Raja Grafindo Persada.

Sujarweni Wiratna. 2015. SPSS untuk Penelitian. Yogyakarta: Pustaka Baru.

Sunyoto, Danang. 2012. Dasar-dasar manajemen pemasaran. Yogyakarta: Cetakan Pertama, Caps.

Sunyoto, Danang. 2013. Teori, Kuisioner, dan Analisis Data Untuk Pemasaran dan Perilaku Konsumen. Yogyakarta: Grahallmu.

Sugiyono. 2012. Metode Penelitian Kuantitatif Kualitatif dan $R \&$ D. Bandung: Alfabeta.

Sugiyono. 2017. Statistika untuk Penelitian . Bandung: Alfabeta Swastha. Basu. 2012. Manajemen Pemasaran Modern. Yogyakarta:

Liberty Tjiptono Fandy dan Chandra Greogorius. 2012, Pemasaran Strategik. Yogyakarta: Andi. Tjiptono Fandy. 2016, Pemasaran Esensi \& Aplikasi. C.V Andi Offset. Yogyakarta. 